\title{
Cecropia purpurascens, a new species for Brazilian Amazonia
}

\author{
C. C. Berg (*)
}

\begin{abstract}
A new species of Cecropia, C. purpurascens C.C. Berg is described. Although it is common in the vicinity of Manaus, it has been overlooked previously because Cecropia is still a poorly studied genus. This new species is quite distinct from related species and is inhabited by ants of the genus Azteca.

This new species is one of the 8 Cecropia species common in the vicinity of Manaus; it is even the most attractive one. In spite of its commonness and its distinctiveness it was rarely collected, and up until now was known by its local name only. This is not surprising for a member of a genus which has been ignored or little studied previously.
\end{abstract}

Cecropia purpurascens C. C. Berg nov. spec.(') (Fig. 1 e 2)

Arbor mediocris. Folia 6-7-lobata, parte superiore sinus medium laminae non attingentes, parte basali lamina vix incisa. Lobus centralis venis secundariis $8-10$-jugis, ad $4 \mathrm{~cm}$ inter se distantibus, ad marginem curvatis, intra marginem arcuatim conjunctis; margo indumento denso albo arachnoideo. Inflorescentia staminifera pedunculo patente; spicae $15-20,7-13 \mathrm{~cm}$ longae, $0.3-0.6 \mathrm{~cm}$ diam., plus minusve angulares, stipitibus $1-2 \mathrm{~cm}$ longis. Rachis glabra. Flores connati. Inflorescentia plstillifera primo pedunculo patente; perianihium apice fere truncato, muriculato; stylus pilis minutis; stigma truncatum, comosum; endocarpium tuberculatum.

Typus: Berg \& Steward P. $18808\left({ }^{2}\right)$ \& , Estrada do Aleixo, Companhia de Plantações, near Manaus (holo-, INPA; iso-, K, MO, NY, P, U, US).

Paratypus: Berg 281 ô, Manaus-Caracaraí road, about km 65 (INPA, NY, U).
Flowering trees $6-15 \mathrm{~m}$ tall, trunk $10-30 \mathrm{~cm}$ in diameter, stilt roots up to $\mathrm{ca} .50 \mathrm{~cm}$ high in older specimens. Leafy twigs $\mathrm{ca} .1-5 \mathrm{~cm}$ in diameter, green with white elliptic spots, scabrous due to minute rigid hairs with a swollen base, this indument intermixed with longer (up to $0.5 \mathrm{~mm}$ long) curved to uncinate hairs and, moreover, brown pluricellular hairs.

Leaves suborbicular to broadly elliptic, ca. $20 \times 20$ - ca. $65 \times 60 \mathrm{~cm}$, subcoriaceous. (5-) 6-7-lobed, midlobe ca. $15-45 \mathrm{~cm}$ long, upper incisions usually not exceeding half the length of the lamina, the base of the lamina little or hardly incised, lobes obtuse to shortly acuminate at the apex; margin faintly repand, bearing a conspicuous (as compared with the other parts of the lamina) white arachnoid indument; upper surface not shining, scrabridulous due to minute rigid hairs, which are intermixed with numerous red-brown pluricellular hairs; lower surface hirtellous on the main veins, which sometimes also bear white arachnoid hairs, and with numerous red-brown pluricellular hairs on the veins, minutely white arachnoid-tomentellous in the areoles; the veins plane above, the main ones yellow, but red in young leaves; veins prominent beneath, red, turning paler red to almost green with age; the free part of the midsegmerit with ca. 8-10 pairs of lateral veins, up to $4(-5) \mathrm{cm}$ from each other, curved towards the margin and forming submarginal connecting loops; young leaves red (dish); petioles 20-50 $\mathrm{cm}$ long, ca. $0.3-0.8 \mathrm{~cm}$ in diameter, green, hirtellous, trichilium present; stipules $8-16 \mathrm{~cm}$ long, coriaceous, caducous, occasionally subpersistent, pale red-brown with numerous yellowish stripes, hirsute outside, subsericeous inside.

Staminate inflorescences usually in pairs; patent peduncle, $6-9(-15) \mathrm{cm}$ long, ca. $0.4 \mathrm{~cm}$ in diameter, green with pale green, stripes,

(*) - Institute for Systematic Botany, State University of Utrecht, Netherlands.

(1) - Epithet based on the vernacular name "Imbauba roxa".

(2) - Dr. Prance's collection series. 


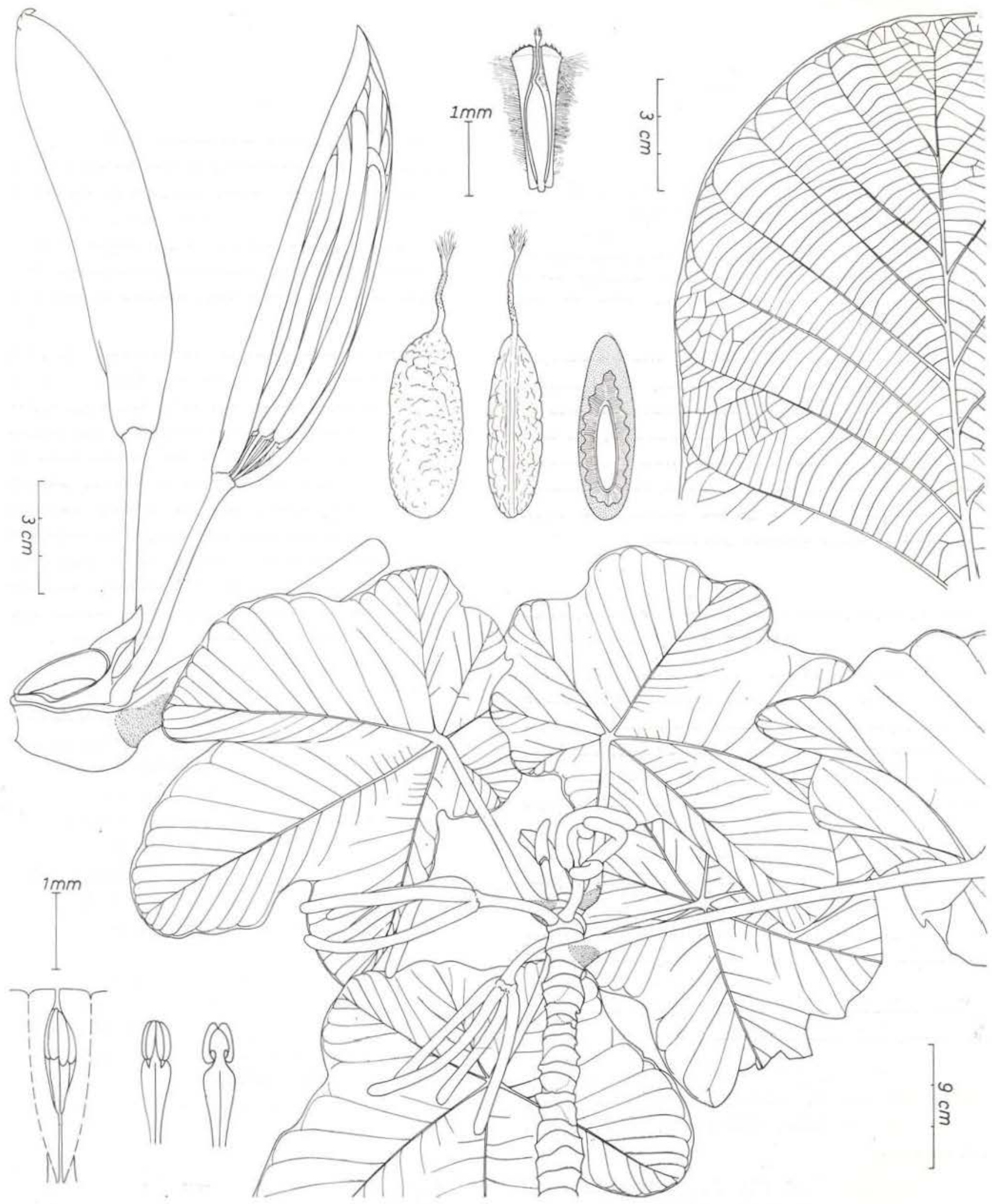

Fig. 1. Cecropia purpurascens C.C. Berg: leafy twig with pistillate inflorescence, leaf segment, pistillate flower, and fruits from Berg \& Stewart P. 18808; staminate flower, and stamens from Berg 281. 


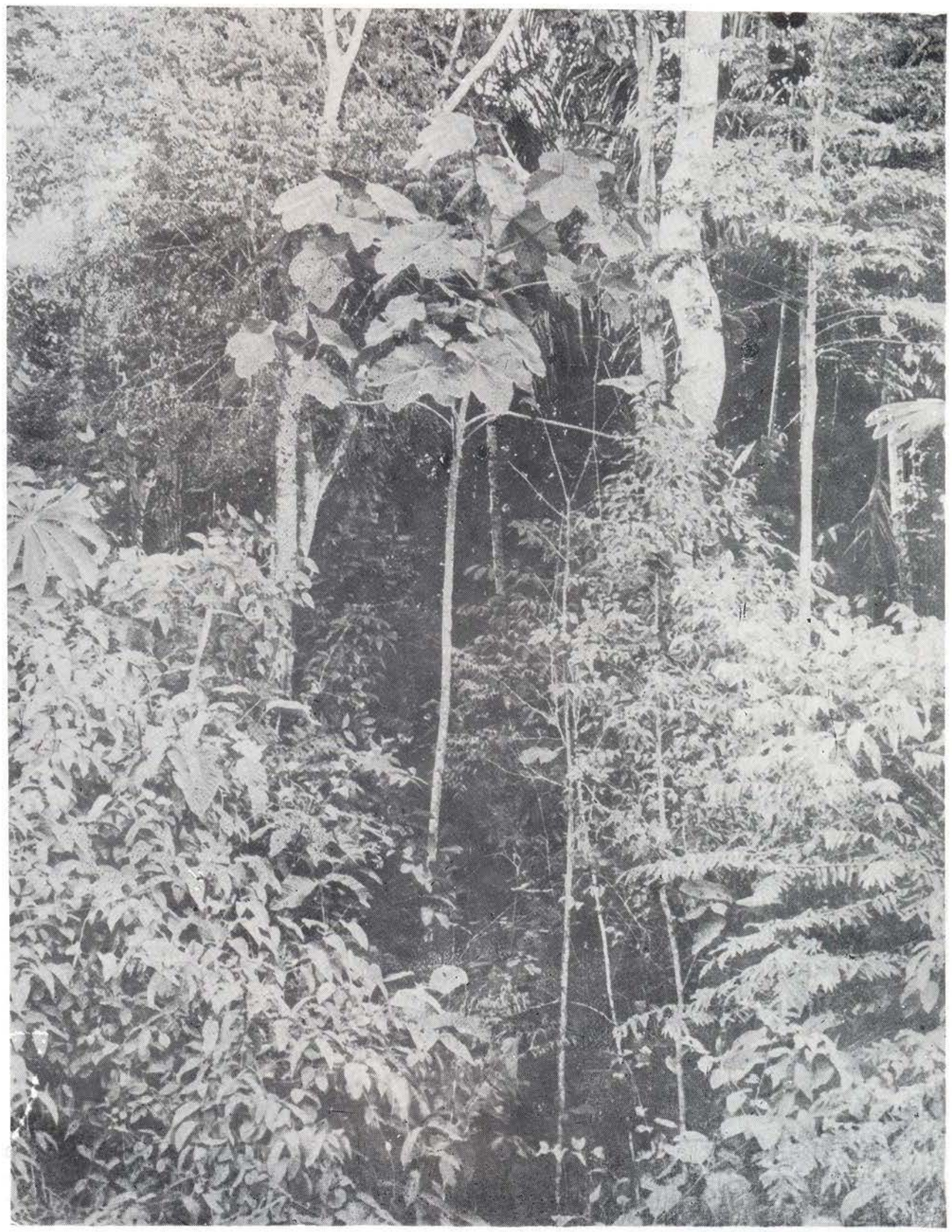

Fig. 2. Cecropia purpurascens C.C. Berg., à margem da estrada do Aleixo, Manaus, Amazonas. (Foto J. Rômulo). 
becoming dark green at maturity, scabrous due to minute rigid hairs, this indument intermixed with longer (up to $0.5 \mathrm{~mm}$ long) curved to uncinate hairs; spatha $12-15 \mathrm{~cm}$ long, grayisn red, turning orange-red with numerous yellowish stripes towards arithesis, densely hirtellous outside, and, moreover, with dense brown pluricellular hairs; spikes ca. 15-20, 7-13 cm long, $0.3-0.6 \mathrm{~cm}$ in diameter, more or less angular, stipitate; stipes $1.2 \mathrm{~cm}$ long, yellow to pale red; rachis glabrous; flowers connate; perianth ca. 1.5-2.5 mm high, somewhat succulent, apex truncate, glabrous; stamens 2, filaments ca. $1.2 \mathrm{~mm}$ long, flat, basally connate, anthers ca. $0.4-0.5 \times 0.3 .-0.5 \mathrm{~mm}$, thecae appendiculate.

Pistillate inf́lorescences usually in pairs, peduncle patent, $6-10 \mathrm{~cm}$ long, ca. $0.3-0.4 \mathrm{~cm}$ in diameter, green with paler or darker green stripes, indument similar to that of the staminate inflorescence; spatha 8-12 cm long. coriaceous, yellowish at first, grayish green later on, densely hirtellous outside, and, moreover, with dense brown pluricellular hairs and sometimes also with white arachnoid hairs, glabrous inside; spikes $4,8-13 \mathrm{~cm}$ long nd $\mathrm{ca}$. 0.4 (in fruit) $1 \mathrm{~cm}$ in diameter, subsessile to stipulate, stipes up to $\mathrm{ca} .0 .5 \mathrm{~cm}$ long; rachis with stiff hairs up to $1 \mathrm{~mm}$ long; perianth ca. $2 \mathrm{~mm}$ high, the apex almost truncate and with minute swollen hairs, below the apex with dense white arachnoid hairs, in the inner surface also with white arachnoid hairs; style iong, with minute hairs, stigma truncate, comose.

Infructescences usually more or less pendulous; fruit oblongoid, ca. $2.5 \mathrm{~mm}$ long. more or less compressed, slightly tuberculate, apex and base obtuse, endocarp tuberculate.

Chromosome number: $2 \mathrm{n}=28$, counted in root tips of material grown from Berg \& Steward P. 18808, under number 73-359, in the Botanical Gardens at Utrecht.

Cecropia purpurascens can be recognized by the relatively short and broad lobes of the leaves. The midlobe has ca. $8-10$ pairs of lateral veins, which form submarginal connecting loops. The arachnoid indumentum is most conspicuous on the leaf margin; it also occurs, albeit very short, in the areoles on the lower leaf surface, as well as sparsely, on the main veins. Connate staminate flowers do not occur in other Amazonian species. The pistillate inflorescences and flowers do not have distinctive characters. Particularly in young specimens, in which the leaves may attain considerable size (up to $1 \mathrm{~m}$ long), the upper leaf surface is usually deep green with a purplish shade.

C. purpurascens is common in the area extending northwards and eastwards from Manaus, and is known from two localities in Pará, North of the Amazon River, between the Paru and the Paru de Oeste Rivers. In its ecology it seems to approach C. sciadophylla. These two species can be found in more or less disturbed or open places in non-inundated forests, such as occur on slopes near streams or in accidental clearings. They appear abundantly in newly cleared places as made for roads and for agriculture. They are less common or even rare in repeatedly disturbed places or on soils depleted by agriculture.

Adult trees of $C$. purpurascens are commonly occupied by Azteca ants.

\section{ACKNOWLEDGMENTS}

The author is much indebted to the Instituto Nacional de Pesquisas da Amazônia at Manaus and Dr. G. T. Prance for the opportunities to study Cecropia, to the Netherlands Foundation for the Advancement of Tropical Research (WOTRO) for a grant to visit Brazil, to $\mathrm{Dr}$. K. U. Kramer for the latin diagnosis, to Drs. L. Y. Th. Westra for the correction of the english text, and to Mr. H. R. Rypkema for making the drawing.

\section{Resumo}

Neste trabalho é descrita uma nova espécje de Cecropia, C. purpurascens. Embora seja comum nos arredores de Manaus, não foi descrita anteriormente porque Cecropia é ainda um gênero muito pouco estudado. Esta nova espécie é muito distin. ta de suas afins e é habitada por formigas do gêne. ro Azteca. 